\title{
Söylemsel Psikoloji ve Zihinsel Üslup: Öykü Çözümlemesi*
}

\author{
Doç. Dr. H. Sezgi Saraç Durgun \\ Akdeniz Üniversitesi, Edebiyat Fakültesi \\ İngiliz Dili ve Edebiyatı Bölümü \\ sezgisarac@akdeniz.edu.tr
}

Öz

Zihinsel üslup kişinin zihin akışını, kullandığı dile yansıttığı görüşüne dayanır. Buna göre, bir kişinin kullandığı dilde birçok farklı dilbilim unsurları bulunmakta ve bu unsurlar bireyin zihinsel süreçlerine ş̧ık tutabilmektedir. Konuşmacıya ait bu türden dilbilimsel seçimler farklı zihinsel durumlarla ilişkilendirilir. Sözcük seçimi, sözdizimi, yan anlamlar, geçişlilik ve benzeri dil kullanımları söylemsel psikoloji ve dolayısıyla zihinsel üslup araştırma alanına girer. Bu çalışmanın amacı, yazar Mine Söğüt'ün Annemin O Harikulade Saçları öyküsündeki başkarakterin söylemindeki zihinsel üsluba ilişkin dil unsurlarını incelemektir. Karakterin birincil ağızdan anlattığı bu öyküde farklı odaklayımlar, şimdiki zaman ve geçmiş zaman bağlamlarının bir arada sunumu ve geçişliliğin çeşitliliği metinde göze çarpmaktadır. Öykünün açılışında en fazla somut süreç göze çarpsa da farklı süreçlerin bir arada verildiği bir metinle konunun aktarıldığg görülmektedir. Bu çeşitlilik ve çokluk olgusu, sözcük ve yapı kullanımlarında da 'tekrar' ile kendini göstermektedir. Metindeki biçimsel yinelemeler âdeta bir yankı, vurgulama, öne çıkarma, sayıklama etkisi ile ana karakterin psikolojik ikilemini yansıtmaktadır.

Anahtar Kelimeler: Üslup, Söylemsel psikoloji, Geçişlilik, Odaklayım.

\section{Discourse Psychology and Mind-Style: Short Story Analysis}

\section{Abstract}

Mind-style is based upon the notion that a narrator displays mental processes within his/her language use by utilizing distinctive linguistics elements. Such various linguistic choices made by each speaker are found to reflect individual mental states. Speaker-specific language use in terms of lexical choice, syntax, connotative meaning, transitivity and alike is within the research scope of discourse psychology and thus mental style. This study aims to analyze the short story, Annemin O Harikulade Saçları (My Mother's Marvelous Hair) by Mine Sögüt, regarding the linguistic elements in terms of the mind-style represented in the protagonist's discourse. The protagonist narrates the story from the first-person point of view; nevertheless, while presenting the past and present aspects, both diverse focalizations are interwoven, and transitivity processes are varied. Although the story initiates mainly with the material processes, the content is transmitted via a combination of various processes. Additionally, such variety is observed within the lexical and syntactical choices in terms of 'reiteration' in the text. These structural reiterations create an echo effect, emphasis, foregrounding, and delirium regarding the protagonist's psychological dilemma.

Keywords: Style, Discourse psychology, Transitivity, Focalization.

\footnotetext{
* Bu çalışmanın bir bölümü 28-29 Kasım 2019 tarihleri arasında Isparta Süleyman Demirel Üniversitesinde düzenlenen 19. Deyişbilim Sempozyumunda sözlü bildiri olarak sunulmuştur. 


\section{GİRIŞ}

Gestalt psikolojisine dayanan 'şema kuramı' zihin ve dil arasındaki ilişkiyi açılayan çalışmaların miladı niteliğindedir. Bu kurama göre, bireyin karşılaştığı yeni bir deneyim ya da olgu zihindeki en benzer haliyle ilişkilendirilir, karşılaştırılır ve böylelikle zihinde anlaşılır kılınır. Bu süreç sonucunda, yeni deneyim ilk örnek haline kıyasla değiştirilip ya da benzer bulunup zihinde işlenir (Cook, 1994). Bu kuram, duyuların ve aynı zamanda dilin bilişsel (cognitive) süreçlerine işaret eder. Bu süreçler, günümüz yapay zekâ çalışmalarında ve aynı zamanda metin anlama çalışmalarına da yardımcı olmaktadır. İrdelenen bu süreçler, edebî metnin zihinde (mind) işlenme sürecini açılama konusunda da temel oluşturur. Ayrıca, kişinin kullandığı dil incelendiğinde aslen zihinsel sürecinin takip edilebileceği belirtilmektedir. Fowler (1977) zihinsel üslubu tanımlarken, kişinin zihin akışını kullandığı dile yansıttığı tüm ayrıksı ve farklı dilbilim unsurlarına dikkati çeker. Konuşmacıya ait bu türden dilbilimsel seçimler farklı zihinsel üsluplar ile ilişkilendirilmiştir (Leech ve Short, 1981). Dolayısıyla, kişiye özgü zihin kurgusu, kişinin kullandığı dilin kurgusuna da yansır. Zihindeki biçim, dile biçem olarak yansır ve dönüşür. Sözcük seçimi, sözdizim, yan anlamlar, geçişlilik ve benzeri dil kullanımları söylemsel psikoloji ve dolayısıyla zihinsel üslup araştırma alanına girmektedir (Fowler, 1977, 1986; Leech ve Short, 1981; Semino, 2007; Semino ve Swindlehurst, 1996). Kisaca belirtmek gerekirse, her bir birey tek bir deneyimi farklı sözcük ve dilbilgisi yapılarıyla ifade eder ki bunun da asıl sebebi her bireyin zihninin bilgi ve duyguyu farklı anlamlandırma süreçleriyle işlemesidir.

Zihinsel üslup çalışmalarında zihin ve eğretileme arasındaki bağlantı irdelenmiştir. Zihinsel üslupla dilbilimsel olgunun yakınlığı Fowler, Leech ve Short ile tartışılagelmiş, değişmeceli (figurative) dilin kullanımında bulunan ya da tekrar eden kişileştirmelerde (personification) işaret edilen algılamanın zihinsel üslupla ilişkisine dikkat çekilmiştir. Bilişsel eğretileme kuramının (Lakoff ve Johnson, 1980) ortaya koyduğu savla, zihinsel üslubu yansitan eğretileme örüntüsünün irdelenmesi gereken bakir bir alan olduğuna dikkat çekilir. Direkt ya da değişmeceli olsun, dil kullanımında kişiye ilişkin ipuçlarına ulaşmak mümkündür. Kişi algıladığını dil kullanımına yansıtır ve kendini ifade ederkenki dil kullanımı zihninden ve psikolojisinden bağımsız değildir. Dolayısıyla, eğretileme ve diğer dil kullanımları hem zihinsel üsluba ilişkin bilgi vermekte ve hem de edebî metni okuma keyfini arttırmaktadır.

Edebî metin okumanın en cazip yönlerinden biri de okuyucunun kendisini karakterlerden biriyle -genellikle eserin başkarakteriyle- özdeşleştirerek okumasıdır. $\mathrm{Bu}$ sayede, kişisel deneyimin bir parçası olmadığı halde bir başkasının nasıl hissettiğini, ne düşündüğünü, neler yaptığını deneyimleyebiliriz. Özellikle de üçüncü ve tanrısal bakış açısıyla aktarımın yapıldığı metinlerde, okuyucu karakterlerin zihinlerine, anlatıcının izin verdiği ölçüde, girebilmektedir. Böylelikle, karakterlerin zihinsel süreçlerini öğrenmekte ve bir karakterin ne düşündügünü dinleyebilmektedir (Lodge, 2002). Palmer (2003), zihni ve zihinsel süreçleri tanımlarken iç dünyamızın tüm yönleri olarak tarif eder. Dolayısıyla, düşünme ve algılama gibi bilişsel etkinliklere ek olarak duygular, inançlar, hisler ve mizacı da kapsayan bir çerçeve çizer. Palmer'a (2003) göre, bir metni anlamak karakterlerin zihinlerinin işleyişinin okuyucu tarafından bizzat zihinde canlandırılmasıdır ki ancak böylesi bir yazar-okuyucu iş birliğiyle okuyucu metne anlam verebilir. Yine Palmer, bu süreçte 20. yy. modern romanında görülen içsel anlatının yanı sıra, davranışçı ve ilk örnek 
(prototip) anlatılarında da aynı şekilde zihinsel süreçlerin iş birliği içinde alımlanmasının gerektiğini belirtir.

Genette (1988) anlatıcının bakış açısını üçlü sistemle belirler ve bu sisteme odaklayım adını verir. Sıfır odaklayımda, anlatıının karakterlerin tümünden daha üstün ve her şeyi bilen bir bakış açısı vardır. İçsel odaklayımda, kısıtlı bakış açısıyla içsel konuşmaların aktarımı söz konusudur. Dışsal odaklayımda anlatıcı içeriği bağlamdaki karakterden daha az bilir, karakterlerin düşüncelerine ve duygularına dair seslendirme olmaz. Dolayısıyla daha çok nesnel ve davranışcı olduğu da belirtilir. Fowler (1989) ise anlatının bakış açısını içsel ve dışsal olarak ikiye ayırır. İçsel görüş, karakterin ruhsal halini, tepkilerini, isteklerini, gerçek hayatta bir gözlemcinin yakalayamayacağı netlikte ve raporlar şekilde anlatımla sağlar ki bu da dramatize edilmişs şekilde kendi kendine konuşma, içsel monolog ya da zihin akışı teknikleriyle verilir. Dışsal görüş ise farklı nedenlerle de olsa karakterden yabancılaşma ve ayrılmayı işaret eder. Edebi metinlerde bu tarz anlatıma en uygun örnek karakterin tanınmadığı, uzaktan gözlemlenerek betimlendiği ya da garip davranışlarda bulunan karakterin ayrıntılarla aktarılması yoluyla olur. $\mathrm{Bu}$ dişsal perspektifin sağladığ yabancılaştırma tekniği kullanılarak karakterin gizemli kılınması da mümkündür. Kimi durumlarda böyle bir aktarım, anlatıcı ve karakter arasına mesafe koyar ve dışsal görüş karakteri ulaşılmaz ve anlaşılmaz bir tavırla nakleder.

Kişisel gerçekliğin zihinde nasıl resmedildiğini, kişisel deneyimlerin nasıl anlamlandıııldığını ve bunun dile dilbilimsel olarak nasıl yansıdığını Dizgesel İşlevsel Dilbilgisi (DID) kuramı geçişlilikle (transitivity) açıklar (Halliday, 1994). DİD, Halliday tarafından geliştirilmiş, dili insan deneyimlerini aktaran, nesneleri adlandıran ve bunları sınıflandıran, sınıflandırmayı da içeriklerine göre tekrar derleyen anlamlar dizgesi olarak kavramsallaştırır. DİD'e göre, dil karmaşık bir göstergesel dizgedir ve farklı katmanları olan ancak eş zamanlı hareket eden işlevlerin eşliğinde yönetilir ki bunlar, sözcükdilbilgisi katman, anlamsal katman ve sesbilgisi katmandır. Tüm bu katmanlar, üst işlevsel bağlam ile dizinlenir. Üst işlevsel bağlam üç farklı grupta tanımlanmıştır. Bunlardan ilki düşünsel (ideational) üst işlevdir ve insan deneyimini aktarır. İkincisi kişilerarası (interpersonal) üst işlevdir, hitap edilen kişiye ve ne hakkında konuştuğumuza ilişkin ifadeyi ve tutumu işaret eder. Son olarak da metinsel (textual) üst işlevdir ve metnin nasıl yapılandırıldığını kapsar (Halliday, 1985).

Edebi metinlere geçişlilik kapsamında bakmak metni yapılandıran unsurları daha derin bir şekilde kavramayı sağlar. Geçişlilik ile altı farklı türde söylem süreci belirlenmiştir. Her bir süreci belirleyen, cümledeki eylemdir. Somut süreç, söylemdeki yapma ve etme durumlarını işaret eder. Zihinsel süreç ise düşünme, algılama ve hissetmeye ilişkindir. İlişkisel süreç, olma durumudur. Bunların dışında ise söyleme, davranış ve var olma süreçleri bulunmaktadır (Halliday, 1994). Geçişlilik, söylemde iletilen olaylara ilişkin akışta önceleme (foregrounding) ya da arkalama (backgrounding) sağlar (Hopper ve Thomson, 1980). Geçişlilik, düşünsel dil işleviyle ilintilidir ve düşüncelerin karşı tarafa nasıl aktarıldığına odaklanır. İşlevi, fiziksel olsun olmasın tüm olayların, durumların ya da ilişkilerin eylem aracılığıyla aktarılmasıyla gerçekleşir (Halliday, 1985, 1994; Halliday ve Matthiessen, 2006). Edebi metinde karakterlerin söylemleri zihinsel olarak olayları, olguları, kişileri nasıl anlamlandırdıklarını anlayabilmemiz için kaynak oluşturur. Geçişlilik özellikleriyle edebi metindeki karakterlerin ifadeleri incelendiğinde, psikolojik bağlamda

SEFAD, 2020; (44): 251-262 
karakterin neleri öncelediği ve neleri ötelediği gibi unsurları belirlemek mümkün olmaktadır.

Bu çalışmanın amacı, yazar Mine Söğüt'ün Annemin O Harikulade Saçları öyküsünde, başkarakterin söylemi ile sunulan zihinsel üsluba ilişkin odaklayım, geçişlilik, sözcük ve yapı kullanımlarındaki dil unsurlarını incelemektir. Söğüt, bu eseri Deli Kadın Hikayeleri (2019) başlıklı kitabında okurlarıyla paylaşır. Kitapta toplam yirmi bir öykü bulunmaktadır. İlk baskısı 2011 yılında yapılan bu kitap, 2019 senesinde yirmi birinci baskıya ulaşmıştır. Annemin O Harikulade Saçları (s. 11-13) öyküsü, kitabın ilk öyküsüdür. Söğüt, her öykünün başında şiir formatında metinler paylaşır. Yazar, şiir formatındaki bu metinleri, Aksakal'a (2014) verdiği bir röportajında "lirik anlatılar" olarak tanımlar ve şiir olarak adlandırmaktan imtina ettiğini belirtir. Kitaptaki ilk lirik anlatı diğerleri gibi sayfa numarası verilmeden paylaşılmaktadır ve bir anlamda hem ilk öyküye hem de kitapta yer alan tüm öykülere giriş yapar niteliktedir:

Size kadınlıkla lanetlenmiş bir varoluş hezeyanı anlatacağım.

Sizi saçlarının ve ayaklarının ucu arasında olup biten

şeylerden ibaret,

doğurmaya mahkûm,

çocuklarını kaybetmekle mühürlü,

yalnız, yapayalnız bir kalabalıkta dolaştıracağım.

İçlerine açılan kapıların arkasına saklanmış kadınların

delirerek bedenlerinden dışarı açtıkları pencerelerden

bakacağım.

O pencerelerden tekrar ve tekrar ve tekrar kendimi aşağı atacağım.

Yukarıdaki lirik anlatı, öykü temasının girizgâhı ve aynı zamanda “... yalnız, yapayalnız ..." ve "... tekrar ve tekrar ve tekrar..." ifadelerinde sunulan dil özelliğiyle de öykünün tekrar özelliğini sergiler. Bu özellik, öyküde ifade edildiği şekilde "Temrin... temrin... temrin..." (s. 11) ifadesiyle pekiştirilir. Bu çalışmada, ilgili edebî metinde bulunan bu ve benzeri söylem özelliklerinin zihinsel üsluba ilişkin metne kattığı unsurlar incelenecektir.

\section{Odaklayım ve Geçişlilik}

Söğüt (2019), Annemin O Harikulade Saçları öyküsünde, karakterin söylem özelliğiyle farklı odaklayım türlerini harmanlayarak sunar. Aslen başkarakterin ağzından ve aynı zamanda çoğunlukla onun bakış açısıyla anlatılan öyküde, şimdiki zaman ve geçmiş zaman bir arada aktarılır. Bununla birlikte, farklı odaklayımlar tek bir karakterin öykülemesiyle sunulur. Öykü, anlatıcı olan kadın karakterin annesi ve annesinin yaşamı üzerinden oluşturulmuş bir anlatıdır. Öyküdeki karakterler isimsiz, anonimdir. Öyküde zamanların kullanımı okuyucunun ilgisini belirli karakterler üzerinde yoğunlaştırır. Örneğin, şimdiki zamanda sadece anlatıcı ve falcı bulunmaktadır. Geçmiş zamana ilişkin olarak da anneanne, anne, baba ve amca karakterleri bulunmaktadır. Öyküde anlatııı, intihar eden annesinin başına gelenleri anlamaya çalışır. Anlatı sıralamasını belirleyen sözcelem ve öykü zamanlarının akışı iç içedir. Kronolojik olmayan sıralama, Söğüt'ün öyküsünde öne çıkar. Genette (1980) eş zamanlı olmayan anlatı akışını anakroni (anachrony) olarak adlandırır ve anlatı zamanının geçmiş ya da gelecekle ilişkilendirilerek verilebildiğini işaret eder. 
Sözcelem zamanının geçmişle ilişkilendirilerek aktarıldığı bu öyküde, geri dönüş (analepsis) özelliği bulunmaktadır. Başkarakter şimdiki zaman, bir başka deyişle anlatı (sözcelem) zamanı konusunda nettir ve içsel odaklayım ile aktarır:

Aynayı sağ eliyle bana doğru uzatıyor. Bir anda aynada kendimle karşılaşıyorum. Korkuyorum. Korktuğumu anlıyor. Bundan hoşlanıyor. (s. 12)

Ne onunkiler gibi kestanerengiydi benim saçlarım, ne bukleli ne de harikulade. Aksine alelade... Dümdüz, kahverengi, inceliksiz, bir anneden, kendini öldüren bir anneden miras kalmışa hiç benzemeyen, kendi halinde, özelliksiz, incecik, ipincecik, zavallı saçlarım... (s. 12-13)

Ertesi gün yine geldi. Divana oturduk. Karşılıklı. Elinde ayna, aynada ben, bende bu kez aşk ve elem. (s. 13)

Anlatıcı, şimdiki zamanı kullanımının aksine, geçmiş konusunda sorgulayıcı ve tahmin yürütür durumdadır. Üslupta farklı odaklayım harmanı kullanılan kısımlar ayrıca, kadın karakterin şimdiye ve geçmişe ait unsurları bir arada vermesiyle gizemli hale gelir. Anlatıcının geçmişi anlama sürecine dair anneannesinden aktarılan sadece kısıtlı anlatımlar vardır. Bu söylemleri, şimdiki zamanda zihninde tekrarlayarak sorgular. Annesine dair geçmişi, kendisine aktarılanlarla anlamaya ve pekiştirmeye çalışır. İlişkin duruma aşağıda verilen incelemede, annesinin intihar etmesinden sonra cesedi gören anneanne anlatılmaktadır. Metinde yineleme tırmanma (climax) yaratarak duygu durumunu şiddetlendirerek aktarır:

Tablo 1. Odaklayım

\begin{tabular}{l|l}
\hline Hayır! & dışsal, nesnel odaklayım \\
\hline Anneannem telaşla çı̆̆lık atmıştır. & içsel, öznel odaklayım \\
\hline Hayır! & dışsal, nesnel odaklayım \\
\hline Anneannem kasılıp kalmıştır. & içsel, öznel odaklayım \\
\hline $\begin{array}{l}\text { Anneannem kızının tavandan sallanan bedeninin } \\
\text { ucuna, tam ucuna, ayaklarına sarılıp avaz avaz } \\
\text { bağırmıştır. (s. 12) }\end{array}$ & \\
\hline
\end{tabular}

Yukarıda işaret edildiği üzere, başkarakterin anneannesinin söylemi ("Hayır!") metinde dişsal odaklayımla aktarılır. Daha sonra, başkaraktere ait içsel odaklayım kiplik (modality) ile aktarılır ("Anneannem telaşla çı̆̆lık atmıştır"). Kiplik anlatıcının bilgi durumunu ya da tutumunu işaret eden ifadedir (Palmer, 2003). Kiplik, başkarakterin çıkarımlarını aktardığı iç sesinin anlatıma dahil olmasını sağlamaktadır. Bu anlatım akışı metinde okuyucunun odak değişimli olarak olaylara şahit olmasını sağlar.

Anlatıcının geçmişi anlama sürecine dair anneannesinden aktarılan sadece kısıtlı anlatımlar ve şimdiki zamanda karşılıklı oturduğu 'falcı' bulunmaktadır. Falcı, bir kâhinden farksızdır. Kâhin, gelecekten haber veren bir aracıdır ve insansı (antropomorfik) bir tanrının birincil ağızdan ifadelerini aktarır (Diethrich, 1990). Ancak, bu noktada zamanı altüst eden bir unsur ortaya çlkar. Bu öyküde falcı, kehanetlerini gelecek için değil geçmiş için yapar: 
Bir adam varmış, dedi. Babanla aynı anadan doğmuş, dedi. Anana âşık olmuş, dedi. Kimselere söylememiş, dedi. Karasevdaya tutulmuş, dedi. Hocaya götürmüşler, dedi. Hoca suya bakmış, dedi, bu adam kestanerengi saçları bukleli bir kadına sevdalı demiş, dedi. (s. 13)

Başkarakter öyküde geçmişte olanları başka bir karakterin aktarımından yola çıkarak kelimelere döker: "Falcı görmediğim rüyalardan bilmediğim bir öykü yazdı" (s. 13). Kendisinin deneyimlemediği, ancak başkasından edindiği böylesi bir bilgiyle, dışsal bir perspektife maruz bırakılarak, dolaylı yani başkasının etkisi altında olay örgüsünü ayrıntılandırır. Bu durum anlatımın içeriğinin tarafsız bir gözle anlatılmasına ve dolayısıyla anlatımın okuyucu tarafından daha nesnel bir şekilde alımlanmasına katkıda bulunur. Kâhin falcı, karakterden daha fazla bilgi sahibi olduğu için anlatım bir anlamda sıfır odaklayım nesnelliğinde ve bilgeliğinde gelişir. Böylelikle okuyucu üzerinde tarafsız bir anlatıma şahit olma etkisi yaratılır. Bu tarz bir anlatım tekniği ile söylemde eşzamanlılık da yaratılarak olay örgüsünü oluşturan eylemlerin sıralamasının netliği de önemi de ortadan kaldırılmış olur. Anlatıda iki ana eylem 'saçları kesmek' ve 'kardeşi öldürmek' öyküde öncelenir:

Babam, kardeşini öldüren o adam, elinde kör makas, annemin saçlarını kesti. Önce kardeşini öldürdü sonra annemin saçlarını kesti. Önce annemin saçlarını kesti sonra kardeşini öldürdü. Babam kardeşini öldüren o adam. Bir annemin saçlarını kesti, bir kardeşini öldürdü, bir annemin saçlarını kesti, bir kardeşini öldürdü... (s. 13)

Yukarıdaki kısım öykü zamanını işaret eder. Sonrasındaki aktarım sözceleme zamanına aittir: “Falcı aynada kör bir makas gördü." Dolayısıyla, öykü zamanı ile sözcelem zamanı belirsiz aralıklarla sunulmakta, bununla ilişkili olarak odaklayım da değişebilmektedir. Öykü zamanına ait içerik belirgin hale gelene dek dilbilimsel ikilik ve yineleme gözlemlenmektedir.

Odaklayıma ek olarak, geçişliliğin çeşitliliği de metinde göze çarpmaktadır. Öykünün açlışında en fazla somut süreç göze çarpsa da farklı süreçlerin bir arada verildiği bir olay örgüsüyle konunun aktarıldığı görülmektedir. Tüm bu karmaşa ve gizem, ("oturdu”, "bir rüyanın" ifadelerinde görüldüğü gibi) belirsiz gösterim (deixis) kullanılmasıyla ve bilmekle bilmemek bağlamında paradoksal bir durumun oluşturulması yoluyla kuvvetlenir:

Tablo 2. Geçişlilik

\begin{tabular}{l|l}
\hline $\begin{array}{l}\text { Hiç görmediğim bir rüyanın yorumunu yapmak için } \\
\text { karşıma oturdu. }\end{array}$ & somut süreç \\
\hline $\begin{array}{l}\text { Rüyayı görmediğimi ben biliyordum. O bilmiyordu. } \\
\text { Söyleyeceklerini o biliyordu, ben bilmiyordum. }\end{array}$ & zihinsel süreç \\
\hline “Temrin... temrin... temrin...” & sözel süreç \\
\hline $\begin{array}{l}\text { İçimizde, bilmenin hazin lütfuyla bilmemenin o tuhaf } \\
\text { hafifliği ... }\end{array}$ & varoluşsal süreç \\
\hline $\begin{array}{l}\text {... alçak divanda karşlıklı, yüz yüze, göz göze merak } \\
\text { meraka oturuyoruz. (s. 11) }\end{array}$ & somut süreç
\end{tabular}

Öykünün içeriğinde kendini asan anneye ilişkin geçişlilik, annenin işteş gibi görünen, anlatıcının amcasıyla yaşanmış olması muhtemel 'aşk' sürecine ve sonrasında gelişen eylemlere dâhil olup olmadığını gösterir. Öyküde bu süreç az farkla iki defa anlatılır ve 
anlatım ikileme ve paralellik ile sunulmaktadır. Annenin dahil olduğu süreçlerin tamamı aşağıdaki gibidir:

Tablo 3. Geçişlilik / Süreçler

Kestanerengi bukle bukle saçları varmış kadının, dedi.

Kendini asmadan önce saçlarının buklelerini kör makasla teker teker kesmiş, dedi.

\begin{tabular}{l|l}
\hline Kendini asmadan önce bir bebeği öpmüş, dedi. & somut süreç \\
\hline ... Kestanerengi bukle bukle saçları varmış kadının, dedi. & varoluşsal süreç \\
\hline Kendini asmadan önce bir bebeği öpmüş, dedi. (s. 13) & somut süreç
\end{tabular}

Dolayısıyla, öykü zamanında sadece 'saç' imgesi ile varoluşsal süreci aktarılan bir anne bulunmaktadır. Annenin varoluşu, güzelliği vurgulanarak ve tek bir imgeye indirgenerek tasvir olunur. Anneye ilişkin, okuyucuya iletilen daha nesnel değerlendirmeler ise somut süreç aracılığıyla yaptı̆̆ı eylemlerle ifade edilir. Anneye ilişkin bu somut süreçler, "dedi" ifadeleriyle sözel süreçler aracılığıyla aktarılır. Bunlardan ilki olan "saçlarının buklelerini kör makasla kesti" süreci, anlatımın tekrarında yer almamaktadır. Tekrarında, aynı eylemin kocası tarafından yapıldığı yer alır. Dolayısıyla, eylemin kimin tarafından gerçekleştirildiğine ilişkin şüphe oluşur.

Anne tarafından yapıldığı kesinlik kazanan eylemler metinde yine somut süreçle aktarılır. Metinde geçişlilikle, annenin sadece iki somut süreci, iki defa tekrarla teyit edilerek aktarılır. Bunlar, "bir bebeği öpmek" ve "kendini asmak" eylemleridir. Her iki eylem de metinde ikişer defa tekrarlanarak âdeta gerçekleştiklerine dair okurun emin olması sağlanır. $\mathrm{Bu}$ iki somut süreç dışında, anneye ilişkin eylem işaret eden başka hiçbir süreç bulunmamaktadır.

\section{Sözcük ve Yapı Kullanımları}

Öykünün üslubunda odaklayım ve geçişlilikte gözlemlenen çeşitlilik ve çokluk olgusu, sözcük ve yapı kullanımlarında da 'tekrar' ile kendini göstermektedir. Somut süreç ifadesinden hemen sonra devam eden zihinsel süreç söyleminde ifade tekrarları ("biliyordu" ve "bilmiyordu") bağlaç eksiltisi (asyndeton) ile kopukluk yaratılarak verilmekte, bu zıtlık olumsuz ifade ile ve özellikle de çaprazlama kullanılarak vurgulanmaktadır:

(...) ben biliyordum. O bilmiyordu.

(...) o biliyordu, ben bilmiyordum.

(...) bilmenin hazin lütfuyla bilmemenin o tuhaf hafifliği ... (s. 11)

Metinde geçen "temrin"; tekrarlayarak alıştırma ifadesi, yine tekrar eder halde verilmekte ("Temrin... temrin... temrin...") ve bu tekrar âdeta bir yankı, vurgulama, öne çıkarma, sayıklama etkisi yaratarak eksilti (ellipsis) ile sunulmaktadır. Kime ait olduğu öyküde net olmayan bu özsöz kullanımı, anlatıcının dışında bir ses ile sunulmakta, tırnak işareti ile sunulan tek ifade olarak metinde yineleme ile yer almaktadır. Memmedova ve Şekerci (2009) her yinelemenin deyişbilimsel bir unsur olmadığına dikkati çekerek, deyişbilimsel bir kullanım olarak yinelemede okuyucunun dikkatinin yinelenen ögeye çekildiğini işaret eder. Dikkat çekme hususunda sadece tekrarla değil, "temrin" ifadesinin yinelemesi grafolojiyle de öne çıkmakta, tırnak işareti ile çerçevelenmekte (framing) ve eksiltme de yine şeklen '...' üç nokta ile öne çıkmaktadır.

SEFAD, 2020; (44): 251-262 
Yinelemeler, başkarakterin geçmişi anlama sürecinde zihninde oluşan sözbilimsel (rhetorical) sorularda da görülmektedir. Düzyazının bir özelliği olarak 'yineleme', giderek artan önem sırasıyla sözcük, sözcük grubu ya da tümcelerin sıralanmasıdır (Özünlü, 2001). Bunun yanısıra, öyküde karakter kendi sorduğu sorulara yineleyerek olası cevaplarını da siralar:

Boynundaki ipi usulca çıkarmışlardır.

Usulca...

Usulca?

Bu mümkün mü? Tavana asılı bir bedeni incitmeden boynundan ipi çıarmak mümkün mü?

Mümkün.

İnsanlar ölünce zaman yavaşlar. Usulca vuku bulur ağır zamanlı olaylar... (s. 12)

Öyküde, başkarakterin bu ikilemi anlatıda sayıca fazla ve ardışık yineleme çeşitleri ile de kendisini gösterir. Betimlemelerde dahi görülen tekrar, anlatı dilini sapma ile şiirselleştirir. İkizlemeye ek olarak, çaprazlama, alışılmamış bağdaştırma, çift anlamlı yineleme, koşutluk ve eşdizim gözlemlenir. Leech ve Short (2007), sözdizim ve sözcük kullanımında bu tür değişiklikleri 'ayna imgelemi yapısı' olarak tanımlar:

Tablo 4. Yinelemeler

\begin{tabular}{|c|c|}
\hline $\begin{array}{l}\text {... tavanı yalandan mı yalandan kristal avizeli, duvarı } \\
\text { eski mi eski küflü yeşil badanalı, penceresi umutsuz mu } \\
\text { umutsuz karmakarışı şehir manzaralı, ... örtüsü } \\
\text { düzgün mü düzgün, farbalası pilili mi pilili, ... }\end{array}$ & ikizleme \\
\hline $\begin{array}{l}\text {... yüksek ama küçük, dar ama uzun, dünü bol ama } \\
\text { yarını kesat, ... }\end{array}$ & çaprazlama \\
\hline ... mezar mı mezar oturma odasındaki ... & alışılmamış bağdaştırma \\
\hline $\begin{array}{l}\text {... ayakları demirden ve yerdeki muşambayı delmekle } \\
\text { suçlu - o yüzden, alçak, çok alçak, alçak mı alçak, en } \\
\text { alçak- alçak divanda... }\end{array}$ & $\begin{array}{l}\text { alışılmamış bağdaştırma ve } \\
\text { çift anlamlı yineleme }\end{array}$ \\
\hline $\begin{array}{l}\text {... yeşil, kırmızı, pembe, mor, yeşil, kırmızı, pembe, mor, } \\
\text { yeşil kırmızı, pembe, mor örtülü ... }\end{array}$ & koşutluk ve eşdizim \\
\hline $\begin{array}{l}\text {... karşılıklı, yüz yüze, göz göze merak meraka } \\
\text { oturuyoruz. (s. 11) }\end{array}$ & $\begin{array}{l}\text { ikizleme ve alışılmamış } \\
\text { bağdaştırma }\end{array}$ \\
\hline
\end{tabular}

Yukarıda, metinden örneklenen 'ayna imgelemi yapısı' öyküde vurgulu şekilde öne çıkan eğretilemede kullanılan imgeyle de paralellik gösterir. Bu eğretileme yine bir aynadır. Falcı, başkarakterin yüzüne doğru, kendisini ve karakteri gösterir şekilde ayna tutar ve bu şekilde geçmişe ilişkin kehanetlerini sıralar. Ayna eğretilemesi ile başkarakter zihnindeki anne imgesini sorgular. Annesinin geçmişinin kendi geleceğinde tekrarlanıp tekrarlanmayacağı sorusu sorgulamalarının nedeni durumundadır. Ayna eğretilemesinde 
verildiği üzere anne ile kendisi arasındaki bağ görünür durumdadır. Anneyle kurulan ilişki, Klein'ın (1957/1998) belirttiği üzere çocuğun içselleştirme sürecini oluşturur. Başkarakter, annesinin geçmişini irdeleyerek kendini keşfeder. Dil örgüsünde olduğu gibi zihninde de annesinin varlığı tekrarlanır. Dolayısıyla, metindeki tüm ayna imgelemi yapıları, ayna eğretilemesiyle daha da güçlendirilerek başkarakterin psikolojisine ilişkin zihinsel söylemini oluşturmaktadır:

Aynayı sağ eliyle bana doğru uzatıyor. Bir anda aynada kendimle karşılaşıyorum. Korkuyorum. (s. 12)

$\cdots$

Sonra aynayı kurnaz bir açıyla onun beni, benim onu görebileceğim şekilde çeviriyor. (s. 12)

Falc1, aynadaki bana baktı. Ve anlattı: (s. 13)

Karşımda falcı, elinde ayna, aynada ben, bende annem. (s. 13)

Bunlara ek olarak, öyküde kullanılan eksiltili ifadeler metinde sessizlik ve suskunluk hissini oluşturmaktadır. Başkarakterin annesine, kendisine ve kadınlığa güzellik unsuru bağlamında işaret eden 'saç' imgesine dair ifadeler sessizlik ve eksilti ise sonlanmaktadır:

Annem... (s. 11)

Annenin o harikulade saçları... Annenin o kestanerengi, rüya bukleli harikulade saçları, annenin o saçları... (s. 12)

(...) benim saçlarım ne bukleli ne de harikulade. Aksine alelade... (s. 12)

(...) özelliksiz, incecik, ipincecik, zavallı saçlarım... (s. 13)

Önceleme ile saçlara yapılan vurgu metinde göze çarpmaktadır. Bu önceleme, önyineleme ile karşımıza çıkmaktadır. Önyineleme, "birbirini izleyen tümcelerin başında aynı sözcüğü ya da sözcük öbeklerini kullanmak" olarak tanımlanmaktadır (Özünlü, 2001, s. 259). Yineleme, öyküde devrikleme (anastrophe) ile birlikte daha kuvvetli hale gelmektedir. Metinde karşımıza çıkan 'tekrar' unsuru, başkarakterin annesinin saçlarını vurgularken yinelenir. Bu vurgu metnin devamında, 'kendini asmak' eylemiyle tekrar karşımıza çıkar. Dolayısıyla bu önceleme, eyleyen ve eylem öbeği durumlarına ilişkin bağlamda önemli bir unsur olarak metinde yerini alır:

Anneannem, saçları, derdi başka bir şey demezdi. Annenin o harikulade saçları... Annenin o kestanerengi, rüya bukleli harikulade saçları, annenin o saçları... (s. 12)

Anneannem, saçları, derdi başka bir şey demezdi. Annenin o harikulade saçları... Annenin o kestanerengi, rüya bukleli, annenin o harikulade saçları, derdi saçımı tararken. (s. 12)

Annenin saçları çok güzeldi, derdi hep anneannem saçımı tararken. (s. 13)

SEFAD, 2020; (44): 251-262 
Dün gece rüyanda kendini asan bir kadın gördün, dedi. Kestanerengi bukle bukle saçları varmış kadının, dedi. Kendini asmadan önce saçlarının buklelerini kör makasla teker teker kesmiş, dedi. Kendini asmadan önce bir bebeği öpmüş, dedi. (s. 13)

Dün gece rüyanda kendini asan bir kadın gördün, dedi. Kestanerengi bukle bukle saçları varmış kadının, dedi. Kendini asmadan önce bir bebeği öpmüş, dedi. (s. 13).

Sözcük ve yapı kullanımlarındaki üsluba özgü yer alan yinelemeler, öyküdeki şiirsel duyumsamayı güçlendirmektedir. Dil yapılarında benzerlik ve tekrarlama gibi özellikler dil kullanımındaki estetik ve güzellikle bağdaştırılırken, dilde özellikle simetri ve yapı tekrarlarının önemi de vurgulanmaktadır (Garner, 1974). Söğüt, ikizleme, koşutluk gibi yapılarla kullandığı dili estetize etmekle beraber, önyineleme, devrikleme, eksiltili ifadeler ile şiirsel unsurları da düzyazı içerisinde deneyimlememizi sağlamaktadır. Aksakal (2014) yazar Söğüt'le yaptığı söyleşide Söğüt'ün daha önceki bir röportajında "Şiir yazar gibi düşünüyorum" dediğini hatırlatıp, şiirle olan ilişkisini sorar. Söğüt, "Sanırım çok erken yaşlarda Nazım Hikmet’le zehirlenen bir bilinçaltım var, o yüzden melodisi olan ritmik cümlelerin peşine takılıyorum" demiştir (sf. 17). Bu melodisi olan dil, zihinde daha kalıcı bir etki yaratmakta ve vurguyu artırmaktadır. Mukařovský standart dille şiirsel dil arasındaki farkı tanımlarken dilbilgisi kurallarının sistematik olarak ortadan kaldırıldığına işaret eder ve bu kural karşıtı kullanımların estetiksel etkiyi arttırarak okuyucunun dikkatini aslında dilbilimsel unsurlara çektiğini belirtir (Veltruský, 1980). Mekanikleşmiş ve sıradan dil kullanımındansa sıradışı dil yapısı ve kullanımları anlamı öncelemeyi (foregrounding) sağlamaktadır. Wittgenstein'in (1953, s. 8) bilinen ifadesinde aktardığ1 gibi "bir dili hayal etmek, bir yaşam formunu hayal etmektir." Bireysel dil kullanımına ilişkin bakış açısıyla bu ifade, Söğüt'ün başkarakterin psikolojik durumuna ilişkin 'yaşam formunu' açımlar şekilde yapılandırdı̆̆

\section{SONUÇ}

Öyküde yazarın üslubu, anlatıcı olan başkarakterin psikolojisine dair netlik ve önceleme sağlar. Hem içsel hem de dışsal bakış açısıyla şimdiki zaman ve geçmiş zaman bağlamlarının bir arada sunumu ve geçişliliğin çeşitliliği öyküde göze çarpmaktadır. Öykünün açılışında en fazla somut süreç göze çarpsa da farklı süreçlerin bir arada verildiği bir metin ile konunun aktarıldığı görülmektedir. Sözcelem zamanında zihni net olan karakter, söyleminde de nettir. Ancak, anlatı zamanına ilişkin başkarakterin çelişkileri ve sorgulaması metne yineleme, farklı odaklayım kullanımları, geçişlilikte çeşitlilik olarak yansımaktadır Başkarakterin geçmişi sorgulayan ve sürekli ikilemde kalan psikolojisi zihinsel üsluba yansımıştır ve söylemindeki dil kullanımlarında somut şekilde ikilem, eğretileme, çaprazlama, alışılmamış bağdaştırma ve benzeri unsurlar olarak karşımıza çıkmaktadır. Metindeki biçimsel yinelemeler âdeta bir yankı, vurgulama, öne çıkarma, sayıklama etkisi ile ana karakterin psikolojik ikilemini yansitmaktadır.

\section{SUMMARY}

To Fowler (1977), mind style refers to the presentation of a narrator's mental life through the linguistic elements in his/her language use. That is, the speaker's linguistic choices are indicative of different mental states (Leech \& Short, 1981). The language use specific to a narrator, such as lexis, syntax, connotations, transitivity, and alike, is in the research scope of discourse psychology, thus mind-style (Fowler, 1977, 1986; Leech \& Short, 
1981; Semino, 2007; Semino \& Swindlehurst, 1996). This study aims to analyze the linguistic elements related to mind-style represented in the protagonist's discourse in a short story called Annemin O Harikulade Saçları (My Mother's Marvelous Hair) by Mine Söğüt (2019).

The protagonist narrates the story from the first-person point of view; nevertheless, the interwoven presentation of the past and present aspects is presented via various focalizations. Besides, the variety in the processes of transitivity is another striking feature within the story. Even though the story initiates mostly with the material process, it is seen that the content is transmitted via a combination of various processes. This concept of variety and plurality is observed within the lexical and syntactic choices in terms of 'reiteration' in the text. Such structural reiterations create the effects of an echo, emphasis, foregrounding, as well as delirium regarding the protagonist's paradoxical stance. The stylistic repetitions in lexical and syntactic usages empower the poetic sensation within this short story. Sögüt aestheticizes the language use through the use of gemination and parallelism, and she enables us to experience a poetic diction within a narrative text via anaphora and anastrophe.

Makale Bilgileri

$\begin{array}{ll}\text { Etik Kurul Kararı: } & \text { Etik Kurul Kararından muaftır. } \\ \text { Katılımcı Rızası: } & \text { Katılımcı yoktur } \\ \text { Mali Destek: } & \text { Çalışma için herhangi bir kurum ve projeden mali destek alınmamıştır. } \\ \text { Çıkar Çatışması: } & \text { Çalışmada kişiler ve kurumlar arası çıkar çatışması bulunmamaktadır. } \\ \text { Telif Hakları: } & \text { Telif hakkına sebep olacak bir materyal kullanılmamıştır. }\end{array}$

Article Information

Ethics Committee Approval: Exempt from the Ethics Committee Decision.

Informed Consent:

Financial Support:

Conflict of Interest:

Copyrights:
No participant

No financial support from any institution or project.

No conflict of interest.

No material subject to copyright is included. 


\section{KAYNAKÇA}

Aksakal, A. (2014). Mine Söğüt [Söyleşi]. Kitapçı Dergi (12), 17 Haziran 2019 tarihinde https://www.academia.edu/38164625/Mine_S\%C3\%B6\%C4\%9F\%C3\%BCt_S\%C3\%B6yle\%C 5\%9Fi.pdf adresinden alındi.

Dietrich, B. C. (1990). Oracles and divine inspiration. Kernos [Online], DOI: 10.4000/kernos.984

Fowler, R. (1977). Linguistics and the Novel. London: Methuen.

Fowler, R. (1986). Linguistic criticism. Oxford: Oxford University Press.

Fowler, R. (1989). Linguistics and the novel. London: Routledge.

Garner, W. R. (1974). The Processing of information structure. Potomac, MD: Lawrence Erlbaum Associates, Inc.

Genette, G. (1988). Narrative discourse revisited. New York: Cornell University Press.

Halliday, M. A. K. (1985). An introduction to functional grammar. London: Edward Arnold.

Halliday, M.A.K. (1994). An introduction to functional grammar (2. bs.). London: Edward Arnold.

Halliday, M.A.K. ve Matthiessen, C.M.I.M. (2006). Construing experience through meaning: A language-based approach to cognition. London: Continuum.

Hopper, P. J. ve Thompson, S. A. (1980). Transitivity in grammar and discourse. Language 56(2), 251-299.

Klein, M. (1998). Haset ve Şükran. (O. Koçak \& Y. Erten, Çev.). İstanbul: Metis Öteki Yayınları. (1957).

Lakoff, G. ve Johnson, M. (1980). Johnson Metaphors We Live by. Chicago: University of Chicago Press.

Leech G. ve Short M. (1981). Style in fiction. London: Longman.

Lodge, D. (2002). Consciousness and the novel. London: Secker and Warburg.

Memmedova, B. ve Şekerci, Ö. (2009). Mysteries of style for students of literature. Ankara: Nobel.

Özünlü, Ü. (2001). Edebiyatta dil kullanımları. İstanbul: Multilingual.

Palmer, A. (2003). The mind beyond the skin. D, Herman (Yay. Haz.) Narrative Theory and the Cognitive Sciences içinde (s. 322-348). Stanford, CA.: Center for the Study of Language and Information.

Semino, E. (2007). Mind style 25 years on. Style. 41(2), 153-173.

Semino, E. ve Swindlehurst, K. (1996) Metaphor and mind style in Ken Kesey's One Flew Over the Cuckoo's Nest. Style 30(1), 143-166.

Söğüt, M. (2019). Deli kadın hikayeleri (21. bs.). İstanbul: Yapı Kredi Yayınları.

Veltruský, J. (1980). Jan Mukařovský's Structural Poetics and Esthetics. Poetics Today, 2(1b), 117-157. DOI:10.2307/1772240

Wittgenstein, L. (1953). Philosophical Investigations. (G.E.M. Anscombe, Çev.). Oxford: Blackwell. 